\title{
Poesía del volantín
}

OLANTÍN de los niños, alto, sobre los pueblos, designas tu subida.

Tulipán de papel, sujeto con humo, te caes hacia el Este.

Subi la loma, orillando el cielo.

Ah, más libre que mi alma. errante, solo.

Pasé el invierno detrás de una ventana

y un sol de rocio de repente se paró de la hierba.

De otra parte. de las ciudades. lejos. lejos de aqui.

Sin embargo, orillando el cielo, surgiste en la colina.

Bailas, grave y audaz, como enfermándote.

Hermano de la flecha, asustas las abejas y trepas a tu arco de hilo.

Viento, viento sin presencia, tiendes la cuerda que sostiene el juguete y

encumbras esa frágil alegría.

Mariposa sin suerte, vacilante, ante todo.

Publicas la primavera, más arriba de los manzaneros blancos.

Gota de color, flor hechiza, entusiasmo de todo.

Yo grité sobre la loma, huia lejos, hacia donde arranca la campanada, donde mi amiga está con su triste sonrisa.

o más allá todavia, porque nadie me espera.

Vienes de lejos, corazón mio, y aun te alejas.

Te miro, enredado en la hierba, mirando hacia los bosques y no te reconozco.

Aqui juegas, abres tu abandono en abanico.

Sin embargo, encendida la luz, y la mano en la frente.

Para qué decir esto fué asis, resto se ha muerto.

Es que renace de entre cicatrices la raiz enterrada.

A quién pertenece el blanco viento? Grité solo en el bosque.

Triste. libre de todos, defendiste tu alma.

Tristeza para qué decirla, y huyendo, huyendo siempre. 
Poesia del volantin

A ti. te asocio, compañera.

mi mujer dulce.

Era, sin duda. la que el viento queria arrastrar.

detrás de su trineo. entre mariposas difuntas.

Lejos de la colina, atajando cielo. de pronto vacilas.

Lejos, lejos y ardiendo, alto sobre los árboles.

Tulipán de papel, sostenido con humo en el viento apresurado.

Giras entre sus aspas pesadas de silencio.

PABLO NERUDA. 